of the relation of temperature to the incubation of eggs of the cattle tick and it seems probable that a similar application might be made in determining the time of treatment of the codling moth, though it is hardly probable that it will be necessary in the latter case.

But it is upon a positive and not merely hypothetical knowledge of such controlling forces as temperature that our science must rest and no one can foresee what entirely practical application may be made of it in the future study of new pests as they present themselves for study under new conditions.

The remainder of the proceedings of the 20th meeting of the Association of Economic Entomologists will be given in the next number of the Journal. It has been deemed advisable, in view of its close relation to two papers in this number, to publish at the same time Mr. Hooker's summarized account of our knowledge of the role of ticks in the transmission of disease. The paper was prepared originally for presentation at the meeting and as a part of the symposium on ticks, consequently it is very fitting that it should appear at this time.

\title{
A REVIEW OF THE PRESENT KNOWLEDGE OF THE ROLE OF TICKS IN THE TRANSMISSION OF DISEASE*
}

By W. A. Hooker, Bureau of Entomology, U. Sో. Department of Agriculture.

Not until within the last decade has the importance of insects and related animals as agents in the transmission of disease been fully appreciated. Within this period, however, the progress of our learning has advanced at an astounding rate. It was but fifteen years ago that Smith and Kilborne first demonstrated the role that the cattle tick, Margaropus (=Boophilus) annulatus, plays in the transmission of Splenetic or Texas Fever of Cattle, and only ten years ago that Ross first employed Anopheles in his mosquito-malaria experiments. Today we all know of the mechanical and biological agency of the flies and mosquitoes in the transmission of typhoid fever, cholera, anthrax or charbon, nagana or tsetse-fly disease, surra, malaria, yellow fever, filiariasis and dengue, and of fleas in the transmision of bubonic plague. Together and with the investigation of the Bacteriologist and Protozoölogist has come that of the Entomologist in the study of the life history and habits of the disease-carrying insects. We are all acquainted with the investigations in this country of Dr. L. O. Howard,

*Prepared for presentation at the meeting of the Association of Economic Entomologists, held at Chicago, Illinois, Dec. 27-28, 1907. 
Dr. J. B. Smith, Dr. E. P. Felt and others, supported by federal and state appropriations, making preventive treatment possible.

But it is to the Ixodoidea, or ticks, that I wish to call your attention in a brief review of our present knowledge of their role in the transmission of disease and to show that they are equally as imporant as the flies and mosquitoes in the transmission of disease. The object in preparing this paper is to emphasize the importance of the study of their biology and to encourage a more extensive collection of them by the Entomologist, within whose field of study they distinctly come.

That the importance of the investigations of the Entomologist are appreciated by the medical profession is well shown by the following paragraph taken from an address before the London School of Tropical Medicine by Sir Lauder Brunton, ${ }^{1 a}$ M. D., upon "Fleas as a National Danger," namely: "What is true of the G. (lossina) palpalis is true of other flies also, and as ticks and bugs are likewise most important as carriers of diseases there really ought to be established by government a chair, or, still better, an institute of scientific entomology, well endowed and having attached to it a number of men who could carry on original investigations. Such a chair, or institute, if thoroughly well endowed and having money lavishly expended upon it, would repay the expenditure a thousand-fold, for the study of tropical diseases is becoming to a great extent identified with the study of the insects which transmit them."

Professor C. P. Lounsbury, Government Entomologist of Cape Colony, may well be considered the pioneer in the study of the biology of the ticks. Prior to 1898, at which time he commenced their study, with the exception of the cattle tick, Margaropus (=Boophilus) annulatus, but little was known of their life history and habits. In speaking of their importance and of the opportunities offered in the study of this group, in a paper read before the British Association for the Advancement of Science ${ }^{2}$ in 1905 , he said, "To my mind the ticks present the more profitable field for the student, whether he be interested in the systematic classification of the species, in the determination of habits and metamorphoses, in experimental research in regard to their transmission of diseases, or in the development of pathogenic organisms within the body of intermediate hosts." In reviewing the status of our knowledge he said, "An excellent groundwork for the classification of the species has been made by Professor G. Newman in his Revision de la famille des Ixodides, which has been published in several parts by the Zoölogical Society of France during the last ten years; but very little has thus far been recorded on the internal anatomy of

aThe numerals refer to bibliographical references at end of paper. 
any species (for later work see following paragraphs), and so far as I am aware no one has yet traced the development of a disease organism within the body of a tick as has been so ably done in the somewhat analogous case of malarial organisms in Anopheles mosquitoes. Also very little has been recorded in regard to the habits and metamorphoses of any species other than those of the genus Boophilus."

Since 1905, however, several valuable contributions have been added, including one upon the internal anatomy of Margaropus annulatus by S. R. Williams ${ }^{4}$ and by W. E. Allen. ${ }^{5}$ Mr. Nathan Banks of the Bureau of Entomology now has in manuscript a revision of the ticks of this country, which, when issued, will greatly aid in identification. Koch ${ }^{6}$ has elucidated much of the life cycle of Piroplasma bigeminum, the cause of splenetic or Texas fever, and has succeeded in discovering the first stages of development of Piroplasma parvum, the parasite of African Coast fever, which are undergone in the tick. Christophers, ${ }^{7}$ also Nuttall and Graham-Smith, ${ }^{8}$ have followed the complete life cycle of Piroplasma canis, the cause of malignant jaundice of dogs.

Doctors Smith and Kilborne, ${ }^{9}$ discovering in 1892 the role that the cattle tick, Margaropus (=Boophilus) annulatus, plays in the transmission of the protozoan, Piroplasma bigeminum, the blood parasite causing Texas fever of cattle in this country, paved the way for this new field of investigation. Since that time a number of diseases of man and the domestic animals have been found to be transmitted by these parasites. Subsequent investigation has shown that ticks are the intermediate hosts of species belonging to the disease producing protozoan genus Piroplasma. It has also been shown that several diseases produced by spirochaetæ are transmitted by ticks. The conclusions reached by Dutton and Todd ${ }^{10}$ are that some development of the spirochaetæ of human tick fever takes place in the tick. Koch has found the spirochaetæ to multiply within the egg. Borrel and Marchoux ${ }^{11}$ have found the spirochaetr ${ }^{\mathrm{b}}$ of fowls to develop at $35^{\circ} \mathrm{C}$. in the body of the tick.

In order to show the zoölogical position of these blood parasites (Piroplasma) transmitted by ticks, the following table taken partially from Daniels and Stanton' $\mathrm{s}^{12}$ most excellent work, is given :

bThere is still a difference of opinion as to the structure and relations of the spirilla and spirochaetæ. They have many similar characters but differ (according to some authors), the latter having flagellæ, which place them across the imaginary line from the former into the protozoa, thus being considered as animal life, while the spirilla are bacteria (or lowly organized plants.) Dr. Raphael Blanchard in the Revue Vétérinaire, 1906, p. 86, places all that are pathogenic in the genus Spirochaeta. 
The exact position of some of the spirochaetæ is in question at present but they are believed to belong to the Mastigophora.

It seems probable that blood parasites exist in certain hosts without ill effect, such animals being naturally immune or having acquired immunity. When these organisms are transmitted to the blood of susceptible hosts, however, as are the various species of Piroplasma, a disease of more or less severity results. This is the case with the trypanosome of tsetse-fly disease, which Koch has found to be transmitted from the crocodile to man by the tsetse-fly (Glossina spp.). Again, while the organism producing Rocky Mountain spotted fever has not been discovered, yet Dr. H. T. Ricketts ${ }^{13}$ has produced the disease in guinea pigs by ticks from horses, cows and vegetation and suspects its transmission from the blood of some animal which has served as host.

TABLE SHOWING THE ZOÖLOGICAL POSITION OF THE TICK TRANSMITTED PARASITES, PIROPLASMA SPP.

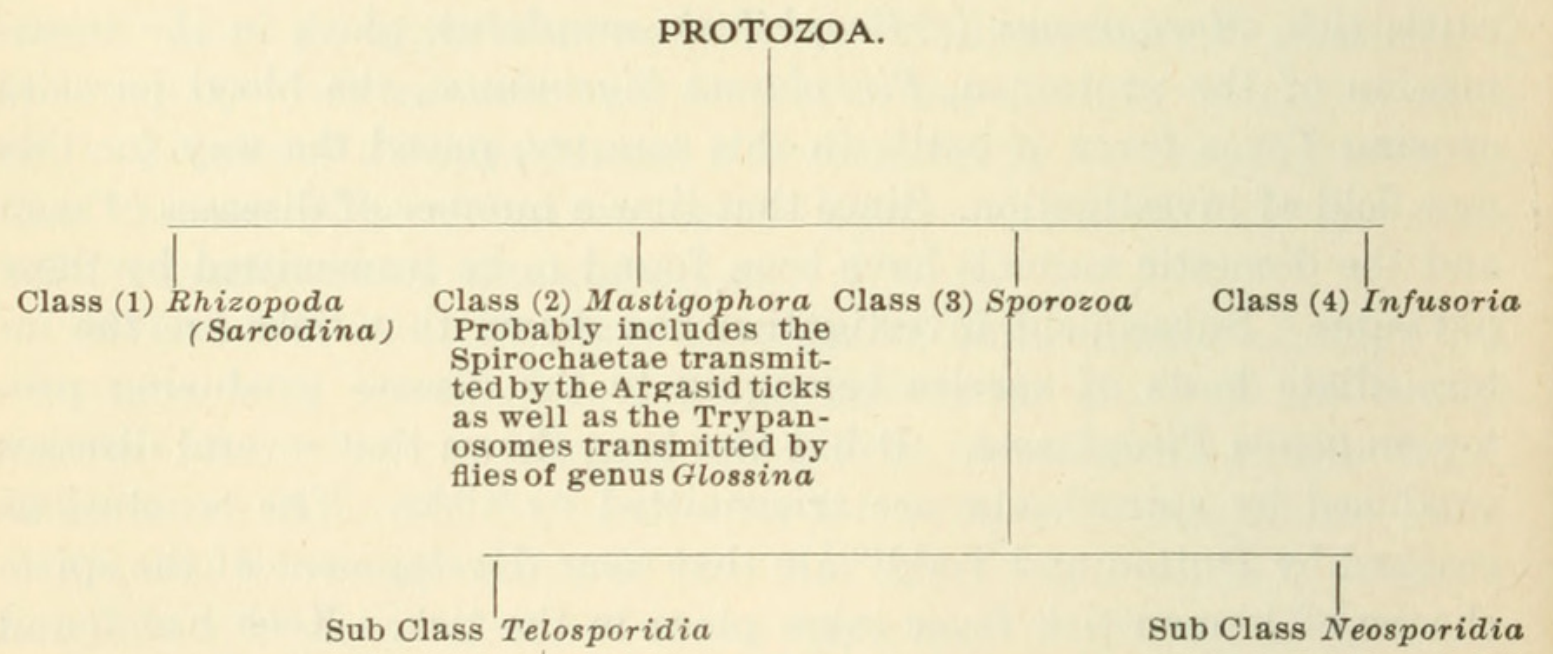

Order (1) Gregarinoidea $\quad$ Order (2) Haemosporidia Order (3) Coccidiidea

(1) Plasmodium (Haemamoeba) Including the malarial parasites transmitted by mosquitoes, of the genus Anopheles

Genera

(2) Haemogregarina
(3) $P$

(4) Halteridium (?)

$P$. bigeminum

$P$. parvum

$P$. ovis.

P. equi

P. canis

Transmitted by the Ixodinid ticks 


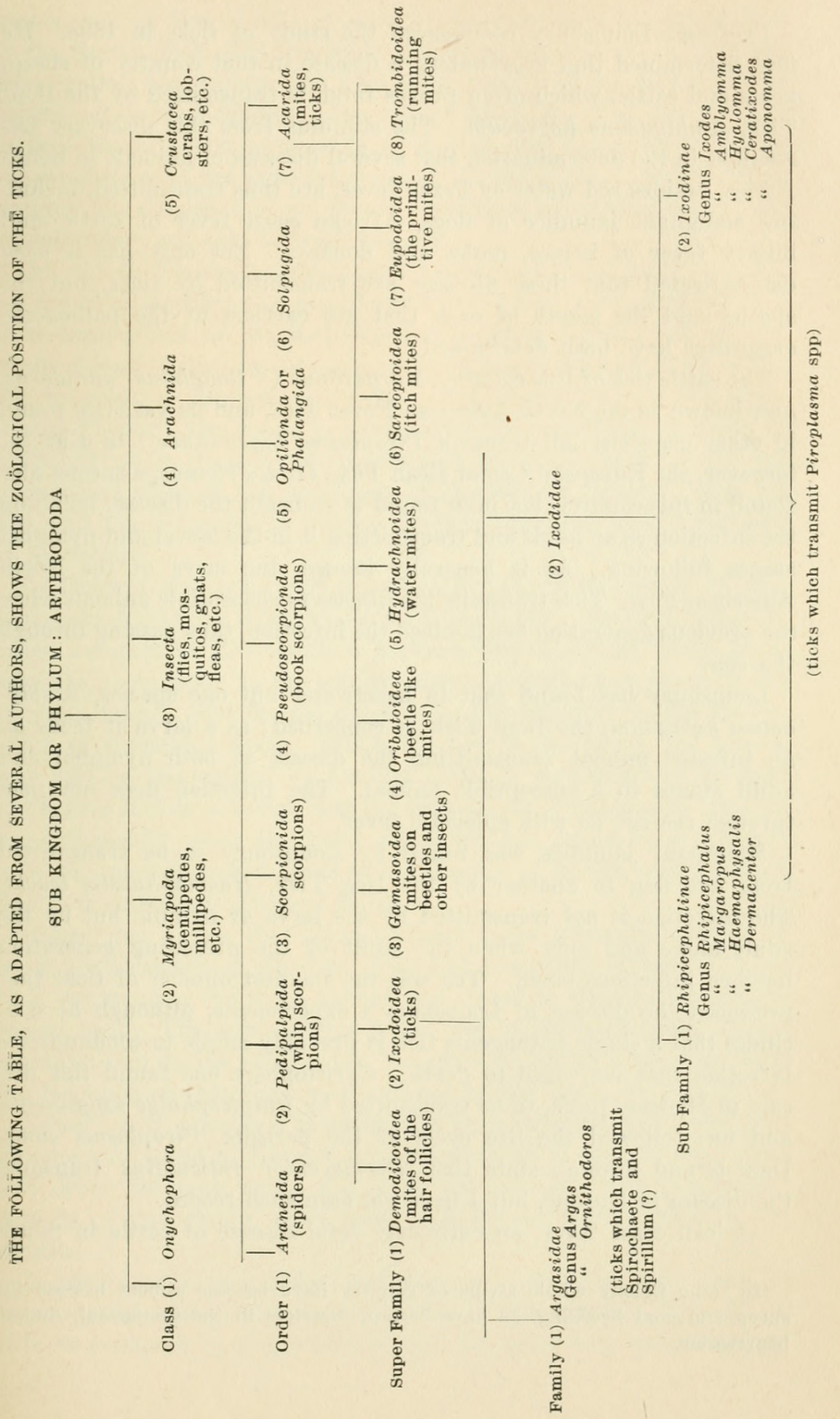


Professor Lounsbury commenced the study of ticks in $1898 . \mathrm{He}$ first determined that heartwater, ${ }^{\mathrm{c}}$ a disease in that country of sheep, goats and cattle, which often proves fatal, is transmitted by the Bont Tick, Amblyomma hebraeum. The stimulus from this discovery has resulted in the determination that several diseases of animals in South Africa, besides red water or Texas fever, are thus transmitted, including malignant jaundice of dogs, African coast fever of cattle, and biliary fever of horses, mules and donkeys. Not only has it been demonstrated that these diseases are transmitted by ticks, but the species and the stages of each that are carriers of the pathogenic organisms have been determined.

The cattle tick of this country, Margaropus (=Boophilus) annulatus, now known as the North American Fever Tick, and its varieties found in other countries, all transmit Piroplasma bigeminum. In Europe, however, the European Castor Bean Tick, Ixodes ricinus, a species also found in this country, has been found to transmit the disease, imbibing the infection as an adult and transmitting it in the larval and nymphal stages following. As is generally known, the larva of the North American Fever Tick transmits the disease to susceptible animals when the previous generation has imbibed the infection, thus passing through the egg.

Lounsbury has found that in heartwater but one species, Amblyomma hebraeum, the Bont Tick, is concerned; as a larva it feeds on an infested animal, transmitting the disease in both nymphal and adult stages to a susceptible animal. The infection does not pass through the egg as with splenetic fever.

Malignant jaundice was found by Lounsbury to be transmitted from one dog to another by the Dog Tick, Haemaphysalis leachi. The infection is not transmitted by the larva or nymph, but by the adult alone and only when the adult of the preceding generation imbibed infectious blood. Ten was the smallest number of ticks that produced the disease in Lounsbury's experiments, although he concludes that a single pathogenic tick is probably ample to communicate infection that may lead to death. Christophers has found this disease in Madras, India, to be transmitted by Rhipicephalus sanguineus, and has followed the life cycle of the parasite, Piroplasma canis. Daniels and Stanton state that Dermacentor reticulatus transmits the disease in Europe, but I have not seen such record.

African coast fever, an extremely fatal disease of cattle in South

cIn Cape Colony whole strips of country have become almost useless for sheep and goat breeding, as have certain districts in the Transvaal, due to heartwater. 
Africa, was at first (1903) thought by Lounsbury to be transmitted by the Brown Tick, Rhipicephalus appendiculatus, alone, but further investigation has proven that four other species of the genus, simus, evertsi, nitens and capensis may also transmit it. The Brown Tick imbibes the infection as a larva or nymph and transmits it in the following stage of the same generation. In the adult stage both sexes transmit the disease, but one or two specimens being necessary. The infection does not pass through the egg.

Dr. Arnold Theiler, ${ }^{14}$ Government Bacteriologist of the Transvaal, has found biliary fever or piroplasmosis of horses, mules and donkeys to be transmitted by the Red-legged tick, Rhipicephalus evertsi, one of the species found by Lounsbury to transmit African coast fever. The infection is imbibed as a nymph and transmitted by the adult. Doctor Theiler ${ }^{15}$ also seems to have shown that spirillosis of cattle in South Africa is transmitted by Margaropus decoloratus. Koch has since found cases of this spirillosis in Daressalem, German East Africa, and has succeeded in tracing the spirochaetæ to within the eggs of the ticks.

To Doctors Marchoux and Salimbeni ${ }^{16}$ belongs the credit of first demonstrating that a tick transmits a spirochaetæ. In 1903 they published a report of their studies, showing that the Fowl Tick, Argas miniatus, is an agent in the transmission of spirillosis in fowls at Rio Janeiro, Brazil. The disease seems to be transmissible by the innoculation of infectious blood. While the tick is one agent, the disease may also be transmitted by feeding blood or excrement of diseased fowls, thus it does not seem that the spirochaetæ is necessarily dependent biologically upon the tick. Balfour ${ }^{17}$ has found what appears to be the same disease of fowls in the Soudan of Africa, and Reaney ${ }^{18}$ that it is endemic in Central India.

Motas $^{19}$ has shown that Rhipicephalus bursa transmits carceag or ovine piroplasmosis in Europe. This tick passes the larval and nymphal stages upon the same animal, but drops to the ground for the second molt. The infection (as is the case of Haemaphysalis leachi) is transmitted by the adult, when the adult of the previous generation has fed upon an infectious host, and not by the larva or nymph.

$\mathrm{Kossel}^{20}$ and associated investigators have demonstrated that piroplasmosis of eattle in Europe is transmitted by Ixodes ricinus. This tick drops for both molts, the larva and nymph being pathogenic. This is of importance, as it may be found to do the same in this country.

In 1905 Dutton and Todd ${ }^{10}$ published an account of their study of the so-called human tick fever in Congo Free State. They found it to be produced by a spirochaetæ that has since been determined by 
Breinl and Kinghorn ${ }^{21}$ to be new to science and described as Spirillum duttoni. This spirochaetæ can be transmitted from animal to animal by the bite of the Tampan Tick, Ornithodoros savignyi var. caecus $(=$ moubata $)$. In the experiments of Dutton and Todd, rabbits, guinea pigs, rats and monkeys were used. The infection was found to pass through the egg. Koch ${ }^{6}$ working independently in German East Africa in 1904 made the same discovery. He found the spirochaetæ to multiply within the egg and that the young ticks from infected localities are capable of infecting monkeys.

Skinner ${ }^{22}$ states it his belief that the ticks common on rats in India transmit the plague bacillus.

The connection between ticks and Rocky Mountain spotted fever of man in this country has been the subject of considerable investigation. Dr. H. T. Ricketts ${ }^{23}$ of Chicago and Dr. W. W. King ${ }^{24}$ of the United States Public Health and Marine Hospital Service have succeeded in transmitting the disease from one guinea pig to another by the application of Dermacentor occidentalis. Later, Doctor Ricketts has produced the disease in a guinea pig through the attachment of 36 males which were collected partly from horses and cows and partly from the vegetation in the vicinity where the disease occurs. This seems to prove that the tick is the natural transmitter of the disease.

For some time it was thought that louping ill, a disease of sheep in Scotland, was transmitted by the European Castor Bean Tick, Ixodes ricinus, but Wheler ${ }^{25}$ recently states that this apparently has been disproven.

Modder ${ }^{26}$ states his belief that the yaws of paranghi disease of man and cattle in Ceylon, which is produced by a spirochaete, is transmitted by a tick. Bettencourt, Franca and Borges ${ }^{27}$ have described from a deer in a park at Mafra, Portugal, a bacilliform plasma which they believe to be introduced into Europe by ticks from zebus in the park.

Laveran and $\mathrm{Nègre}^{28}$ suggest the possible transmission of a disease in an African land turtle, due to a Haemagregarine, by the Bont Leg Tick (Hyalomma aegyptium.)

In this country Professor H. A. Morgan ${ }^{29}$ has studied several species and has determined that neither Dermacentor variabilis nor Amblyomma americanum transmit splenetic or Texas fever. Dr. N. S. Mayo $^{30}$ has reached the same conclusion with the latter species.

Aside from splenetic or Texas fever and Rocky Mountain spotted fever, no disease in this country has been determined as transmitted by ticks, although it is suspected that spirillosis of fowls may occur and be thus transmitted in southwestern Texas. It has also been pointed out to the writer by Prof. H. A. Morgan that hunting dogs 
taken from Louisiana to Cuba often sicken and die, possibly due to a disease transmitted by ticks.

That various parasites exist in the blood of animals, many of which are at present unknown, there can be no doubt, although the great activity along this line of investigation during the past few years has brought many to light.

The possibility that diseases which are transmitted through the agency of ticks may be introduced into this country must be considered. If such a disease as is suggested exists in Cuba, it might be introduced into this country with returning dogs. Prof. Lounsbury states that the malignant jaundice of dogs in South Africa and India has already been introduced into France and that it is likely to be introduced into this country. He states that should Angora goats be brought to this country from South Africa that they might bring heartwater which is so common on the veldts of that country. We trust, however, that the rigid inspection of animals entering this country by the U. S. Department of Agriculture, through the Bureau of Animal Industry, may prevent the introduction of such diseases.

While the scarcity of ticks in the colder sections might exclude the transmission of these diseases, yet in the warmer parts of our country, where the species and individual ticks are numerous, an intermediate tick host might readily adapt itself. It must be emphasized that the prevention of the importation of ticks is not sufficient. The danger is in animals, the blood of which is infectious, that may be attacked by native ticks.

The rapid development in our knowledge of the active agents in the transmission of diseases indicates the opportunities and possibilities that may result from a better knowledge of this group of parasites, and emphasizes the importance of a better acquaintance with the life history and habits of our North American ticks.

In this broad field of investigation it remains for the entomologist in this country to elucidate the biology of the ticks, as has been so ably done in South Africa by Lounsbury.

I have prepared the following table which shows graphically this relation of ticks to disease: 


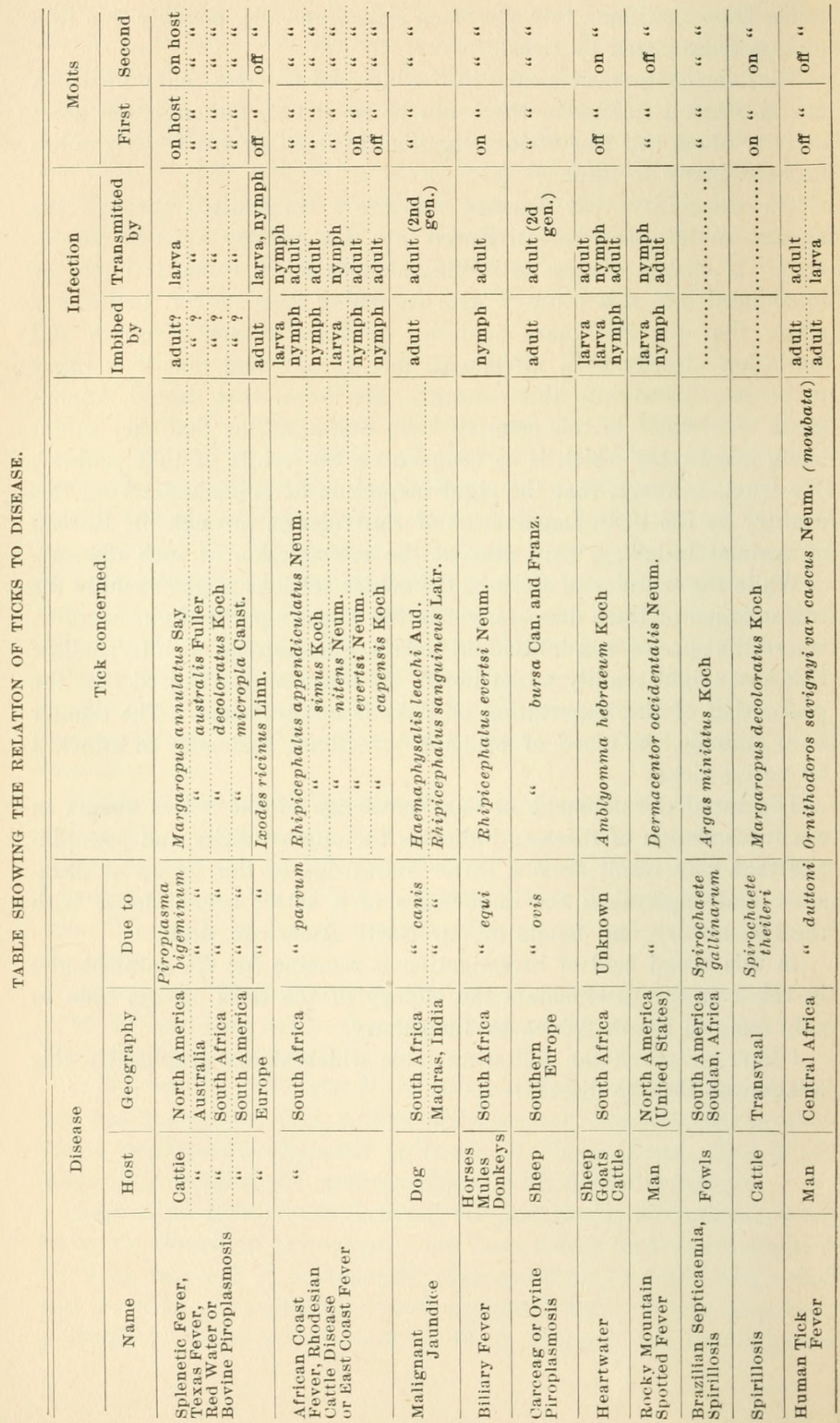




\section{References.}

1. Brunton, C. P. Fleas as a National Danger. Journ. Trop. Med. and Hyg. Vol. 10, 388-391 (Dec. 1907).

2. Lounsbury, C. P. Reports of the Entomologist of Cape Colony, South Africa $1898-1905$.

3. Lounsbury, C. P. Habits and Peculiarities of Some South African Ticks, Report of the British Ass'n for the Adv. of Science 1905 (So. Africa) pp 282-291 (1906).

4. Williams, R. S. Anatomy of Boophilus annulatus Say. Proc. Boston Soc. Nat. Hist. Vol. 32, pp 313-334 (1905).

5. Allen, W.E. Internal Morphology of the American Cattle Tick. Studies from the Zoological Laboratory, Univ. Nebr. No. 67 (1906).

6. Koch, R. Vorläufige Mitteilungen Uber die Ergebnisse Einer Forschungsreise nach Ostafrika. Deutsche Med. Wochser. 31 : 1865-1869 (Nov. 1905). Transl. in Journ. Trop. Med. Vol. 9 (1906).

Beitrage zur Entwicklungsgeschichte der Piroplasmen. Zeitschr. Hyg. und Infektion. 51 pp 1-9 (1906).

7. Christophers, S. R. Preliminary Note on the Development of Piroplasma canis in the Tick. Brit. Med. Journ. No. 2402, pp 76-78 (Jan. 1905). Development of Piroplasma canis in the Tick. Brit. Med. Ass'n., Section of Trop. Dis. 19. Rev. in Journ. Trop. Med. Vol. 10, pp 323 (Oct. 1, 1907).

8. Nuttall (G. H. F.) and Graham-Smith (G. S.) Canine Piroplasmosis VI. Studies on the Morphology and Life History of the Parasite. Journ. of Hygiene, Vol. 7, pp 232-272 (April 1907).

9. Smith (T.) and Kilborne (F. L.) Texas Fever, U. S. D. A. Bureau of Animal Industry, Bull. No. 1, (1893).

10. Dutton. J. E. and Todd, J. L. The Nature of Human Tick Fever in the Eastern Part of the Congo Free State, With Notes on the Distribution and Bionomics of the Tick. Liverpool School Trop. Med., Memoir 17, pp 1-18 (Nov. 1905)

11. Borrel, A. and Marchoux, E. Argas and Spirilles. Comp. Rend. Soc. Biol. Paris. Vol. 58, pp 362-364 (Feb. 1905).

12. Daniels, C. W. and Stanton, A. T. Laboratory Studies in Tropical Medicine. 2nd Ed. (1907).

13. Ricketts, H. T. The Role of the Wood-Tick (Dermacentor occidentalis) in Rocky Mountain Spotted Fever. Journ. Amer. Med. Ass'n. Vol. 49, pp 24-27 (July 6, 1907).

14. Theiler, Arnold. Further Notes on Piroplasmosis of the Horse, Mule and Donkey. Transvaal Agrl. Journ. Vol, 3, pp 706-716 (July 1905). Transmission of Equine Piroplasmosis by Ticks in South Africa. Journ. Comp. Path. and Therap., Vol. 19, pp 283-292 (Dec. 1906).

15. Theiler, Arnold. Transmission and Innoculability of Spirillum theileri. Proc. Roy. Soc. Lond. Vol. 76, pp 504-506 (1905). Transvaal Dept. Agr., Ann. Report Dir. Agr. 1904-1905 (1906).

16. Marchoux, E. and Salimbeni, A. La Spirillose des Paules. Annals l'Institut Pasteur, Vol. 17, pp 569-580 (1903).

17. Balfour, A. A Peculiar Blood Condition, Probably Parasitic in Soudanese Fowls. Journ. Trop. Med. and Hyg. Vol. 10, pp 153-157 (May, 1907). A Spirillosis and a Haematozoal Disease of Domestic Fowls in the Anglo-Egyptian Soudan. Brit. Med. Journ. No. 2413, pp 744-745 (March 1907). 
18. Reaney, M. F. Spirillosis of Domestic Fowls. Brit. Med. Journ. No. 2419 p 1118 (May 11, 1907).

19. Motas, M. Sur le Role des Tiques dans le Développement de la Piroplasmose ovine. Comp. Rend. Soc. Biol. Paris. Vol. 55, pp 501-504 (1903).

20. Kossel H., A. Weber, Schütz and Miessner. Ueber die Haemaglobinurie der Rinder in Deutschland. Arb. K. Gesundheitsamte. Vol. 20, pp 1-77 (1903).

21. Breinl, A. and Kinghorn, A. An Experimental Study of the Parasite of African Tick Fever (Spirochaeta duttoni). Liverpool School of Trop. Med. Mem. 21 (Sept. 1906). Rev. in Journ. Trop. Med. Vol. 9, pp 377-378 (Dec. 1906).

22. Skinner, B. Preliminary Note Upon Ticks Infesting Rats Suffering From Plague. Brit. Med. Journ. No. 2434, pp 457 (Aug. 1907).

23. Ricketts, H. T. The Transmission of Rocky Mountain Spotted Fever by the Bite of the Wood-Tick (Dermacentor occidentalis), Journ. Amer. Med. Ass'n. Vol. 47, p 358 (Aug. 1906).

24. King, W. W. Experimental Transmission of Rocky Mountain Spotted Fever by means of the Tick. Public Health and Marine Hospital Service, 21, pp 863-864 (July 1906).

25. Wheler, E. G. British Ticks. Journ. Agrl. Science. Vol. 1, pp 400-429 (1906).

26. Modder, E. C. The Transmission of Yaws By Ticks. Journ. Trop. Med. and Hyg. Vol. 10, pp 187, 361 (June and Nov. 1907).

27. Bettencourt, A., Franca C. and Borges. I. Bacilliform Piroplasma of Deer. Arch. Real. Inst. Bact. Camara Pestana 1, pp 341-350 (1907).

28. Laveran A., and Nègre. Sur un Protozoaire Parasite de Hyalomma aegyptium. Comp. Rend. Soc. Biol. Paris. pp 965-966 (1905).

29. Morgan, H. A. Ticks and Texas Fever. La. Agr. Exp. Sta. Bull. 56, pp 134-135 (Sept. 1899).

30. Mayo, N. S. Some Diseases of Cattle. Kansas Agrl. Exp. Sta. Bull. 69 (1897).

The eighth annual meeting of the Louisiana Society of Naturalists was held at New Orleans, February 1st. This Society is well known to scientific workers, especially those engaged in research work in the strictly biological sciences, who are located in the Southern States. The Society has a membership of over seventy, many of the members being connected with agricultural experiment stations or with leading educational institutions of the South. The Society's field is a broad one and among its publications are found meritorious papers upon botany, bacteriology, ornithology, animal physiology and invertebrate zoölogy, as well as a considerable number of papers upon various entomological subjects.

On the program was noted the following papers which are of interest to economic entomologists: "Notes upon the Life History and Habits of the Argentine Ant."-Wilmon Newell. "A short account of the Egg and Larva. of a Psychodid."-B. H. Guilbeau. "The Relation of Entomology to Agriculture."-Arthur H. Rosenfeld. "Notes on the sugar cane pou-a-pouche." -J. B. Garret.

Mr. B. H. Guilbeau of Baton Rouge is President and Mr. R. S. Cocks, of Baton Rouge, is Secretary of the Society. 


\section{$2 \mathrm{BHL}$ Biodiversity Heritage Library}

Hooker, W. A. 1908. "A review of the present knowledge of the role of ticks in the transmission of disease." Journal of economic entomology 1(1), 65-76. https://doi.org/10.1093/jee/1.1.65.

View This Item Online: https://www.biodiversitylibrary.org/item/37189

DOI: https://doi.org/10.1093/jee/1.1.65

Permalink: https://www.biodiversitylibrary.org/partpdf/325766

\section{Holding Institution}

New York Botanical Garden, LuEsther T. Mertz Library

\section{Sponsored by}

The LuEsther T Mertz Library, the New York Botanical Garden

\section{Copyright \& Reuse}

Copyright Status: NOT_IN_COPYRIGHT

This document was created from content at the Biodiversity Heritage Library, the world's largest open access digital library for biodiversity literature and archives. Visit BHL at https://www.biodiversitylibrary.org. 